\title{
Cusco, A. (2017): A contested borderland. Competing Russian and Romanian visions of Bessarabia in the late nineteenth and early twentieth century (Central European University Press, Budapest, New York, 338 o.)
}

\author{
ILLÉS TAMÁS
}

\begin{abstract}
ILLÉS Tamás: doktorandusz, Eötvös Loránd Tudományegyetem, Természettudományi Kar, Földrajz- és Földtudományi Intézet, Regionális Tudományi Tanszék; 1117 Budapest, Pázmány Péter sétány 1/C.; tamas.illes92@gmail.com; https://orcid.org/0000-0001-5318-8375
\end{abstract}

Tamás ILLÉS: PhD student, Department of Regional Science, Institute of Geography and Earth Sciences, Faculty of Sciences, Eötvös Loránd University; Pázmány Péter sétány 1/C., H-1117 Budapest, Hungary; tamas.illes92@gmail.com; https://orcid.org/0000-0001-5318-8375

2018. március 13-án a chișinăui (kisinyovi) parlamentben egy olyan törvénytervezetet iktattak, amely a Moldovai Köztársaság Romániával való egyesülését indítványozza. Alig két héttel később a bukaresti parlament egy ünnepi nyilatkozatban hasonló szándékáról tett tanúbizonyságot: „Talán nincs elég bátorságunk kimondani, hogy mit szeretnénk? (...) Én azt akarom, hogy egyesüljünk Moldovával.” (Liviu Dragnea, a kormányzó Szociáldemokrata Párt elnöke). Képzeljük csak el, ha a magyar törvényhozás hasonló lépésre szánná el magát például a felvidéki magyar tömbökre vonatkozóan! A sajtóvisszhang mégis elmaradt. Nem véletlen, hogy a Moldovára jellemző többszörös társadalmi megosztottsággal, sorozatos tüntetésekkel és az európai integráció kudarcával a nemzetközi döntéshozók látszólag nem tudnak mit kezdeni, a moldovai események rendszerint a hegemón geopolitikai diskurzusok leegyszerüsítő sémáiba (pl. Nyugat és Kelet) ágyazódnak. Mindez jelzi az európai posztszovjet térségre vonatkozó ismerethiányunkat és dichotómiák megfogalmazására való hajlandóságunkat, holott a „történelem szinte mellettünk zajlik”.

Andrei Cusco munkája erre a nehezen megfogható terepre kalauzol minket, azt a különleges helyzetet járva körül, ahogyan egy geopolitikai ütközőzónába szorult határ menti régió az orosz birodalom- és a román nemzetépítési törekvések között a szimbolikus hadviselés tárgyává válik. A címben szereplő Besszarábia soha nem volt koherens közigazgatási egység, csupán 1812 és 1940 között jelölte így az orosz közigazgatás (jobb alternatíva hiányában) a Prut, a

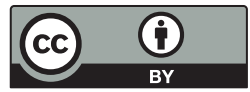


Dnyeszter és a Fekete-tenger közötti területet. A mü elméletileg rendkívül széles alapokra támaszkodik, amelyhez impozáns szakirodalmi háttér párosul. Az elméleti keretek lefektetését követően az empirikus részek szerkezete első ránézésre meghökkentőnek tűnhet, de csak azért, mert Cusco bátran elrugaszkodik a Magyarországon megszokott historicista állásponttól, és a Besszarábia feletti igényt igazoló érvelési stratégiákra nem a történelmi események kronologikus medrén, hanem eltérő dimenziókon keresztül világít rá. A második fejezetben például Dél-Besszarábia - mint gyakran gazdát cserélő pufferzóna - szolgáltat földrajzi keretet a nacionalista és imperialista diskurzusok vizsgálatához. A harmadik fejezet a Besszarábia százéves orosz annektálására („felszabadítására") rendezett állami ünnepségek szimbolikus jelentőségét és az azokra adott román válaszokat öleli fel. A következő fejezetben három Besszarábiából származó, a román-orosz kapcsolatokat meghatározó író (Bogdan Petriceicu Hasdeu, Constantin Stere és Dimitrie C. Moruzi) esszéinek ütköztetéséből a helyi identitások bizonytalanságára és töredezettségére következtet, amelyet csak fokoztak az erősödő nacionalizmusok és osztálymozgalmak. Az utolsó fejezet a Besszarábiáért folytatott szimbolikus versengést az 1. világháború és az azt közvetlenül megelőző időszak feszült diplomáciai kapcsolatainak tükrében vizsgálja.

Amint arra a könyv is rámutat, a magasabb léptékű narratívaütköztetéseket a hatalmi központok (elsődlegesen Szentpétervár és Bukarest, másodlagosan Isztambul és Bécs) vonatkozásában perifériának számító, erőtlen struktúrákkal, vékony értelmiségi réteggel rendelkező Besszarábia érdemben nem tudta befolyásolni. Mind az orosz, mind a román államépítés célkeresztjében az 1860-as évektől jelenik meg a besszarábiai kérdés, amely szorosan összefügg az 1863-as litván-lengyel januári felkelés után perifériáit jobban integrálni kívánó orosz szándékokkal, valamint az ez idő tájt szuverenitását elnyerő Román Királyság fokozatosan kikristályosodó külpolitikai orientációjával és nemzeti törekvéseivel. A vizsgált időintervallum másik határát az 1916-1917-es évek nagy horderejü történelmi eseményei (Románia hadba lépése, az októberi orosz forradalom) rögzítik. A pontos lehatárolás azonban nem jelent merev időbeli kereteket, bőven találkozhatunk olyan korábbi vagy későbbi eseményekre történő utalásokkal, amelyek a kontextus felvázolásához elengedhetetlenül szükségesek.

Jóllehet a mü alapvetően történelemtudományi beállítottságú, fogalomhasználata és ismeretelméleti alapjai nagyban merítenek a földrajz tudáskészletéből, ugyanis a szerző elsődlegesen a diskurzusok földrajzi tartalmaira fókuszál, amelyekből kirajzolódnak a Besszarábiára aggatott, a román és az orosz fél által kölcsönösen befolyásolt régiókonstrukciók. A centrum-periféria dualitáson, valamint a léptékek váltakozásán keresztül értelmezési támpontokat kapunk arról, hogy a távoli központokban kialakított földrajzi képzetek hogyan alakultak át helyi szinten. Cusco számára a földrajzi szempontok érvényesítése tudatos választás eredménye, hiszen véleménye szerint a történészek egyrészt alulsúlyozzák a határhoz kapcsolódó fogalmak jelentőségét, másrészt pedig vonakodnak attól, hogy 
elrugaszkodjanak az állami lépték uniformizált területi kereteitől. A hagyományos megközelítések helyett a könyv a frontierek komplexitásából indul ki, rámutatva a határok instabilitására, a határ menti identitások fluiditására és a hatalomgyakorlás eltérő képzeteire azáltal, hogy e térségek nem a centrum perspektívájából jutnak értelmezési kerethez. A szerző szerint az Orosz Birodalom homogenizált terének dekonstrukciójára és a centrum-periféria viszonyok tükrében annak újraértelmezésére van szükség.

Az elméleti keretek sarkalatos pontja a posztkoloniális kritikai szempontok alkalmazhatósága, amely manapság a posztszovjet térséggel foglalkozó társadalomtudományi munkákban egyre hevesebb vitákat gerjeszt. A szakirodalomban konszenzus mutatkozik abban, hogy az Orosz Birodalom teljes mértékben nem illeszthető be a klasszikus saidi mintába, ugyanis egyszerre volt gyarmatosító és gyarmatosított, tehát a gyarmatosítás tárgya és alanya. Ennek ellenére Besszarábia esetében nem elhanyagolható, hogy az orosz imperialista diskurzusok az 1812 előtti eseményeket az oszmán despotizmussal azonosították, ezzel pedig az új birodalmi berendezkedés civilizáló küldetését legitimálták. Az egzotikus muszlim hagyatékokkal vagy a sztyeppei népek barbarizmusával azonosított „orientalista” kép is hozzásegített ahhoz, hogy Besszarábia stratégiai megfontolásokból a 19. század közepéig megőrizze bizonyos fokú jogi és intézményi autonómiáját, illetve hagyományos társadalmi berendezkedését. A posztkolonializmus használhatóságának másik szempontja az „Én” és a „Másik” diszkurzív előállítása. A cári területek lakosságának jogi felosztása „prirodnije” (orosz nemzetiségü) és „inorodci” (bővülő kategória; civilizálatlannak tartott, de privilégiumokkal rendelkező) népességcsoportokra végső soron ezt a kettősséget intézményesítette. Utóbbi fogalom a nacionalizmus elöretörésével fokozatosan teret nyert a közigazgatásban, az 1905-ös oroszországi forradalom után pedig nemcsak a kulturális különbség gyűitőfogalma, hanem a megbízhatatlan, más etnikumú lakosok pejoratív jelölője is lett.

A szerző hosszasan ecseteli a regionális különbségek jelentőségét a román nemzetépítési gyakorlatokban. A román etnikai tér két súlyponti területe, Erdély és a Regát közötti eltérő történelmi pályák kulturális lenyomata ugyan számos aspektusban felszínre tört, az értelmiségi csoportoknak mégis sikerült egységes nemzeti narratívákat (pl. a dákoromán kontinuitás elmélete) megszilárdítani. Ehhez a közös nemzetépítési projekthez Besszarábia járult hozzá a legkisebb mértékben. Az Orosz Birodalom perifériáin kibontakozó russzifikációnak, valamint a helyi elitek alárendelt és kiszolgáltatott helyzetének együttes hatásaként Besszarábia gyakorlatilag kimaradt a román nemzetfejlődés „közös” élményéből. Ahogy arra a szerző is rámutat, még az etnikailag heterogénebb, Habsburg-uralom alatt álló Bukovinát is hatékonyabban sikerült a román mentális térképen a nemzettest részévé tenni. Ebben a folyamatban érdekes a kényszerűségből a Román Királysághoz kapcsolt Dobrudzsa esete, amelyben Cusco - visszautalva a posztkoloniális elméleti vitákra - sajátos belső orientalizmust, egyben a román mint európai kultúra civilizáló erejének meg- 
mérettetési lehetőségét véli felfedezni. A könyv további erényei közé sorolhatjuk a túlzott általánosítások elleni kiállást. Hiába létezett Besszarábiáról hivatalos orosz vagy román álláspont adott időpontban, ezek mögött rendszerint komoly viták húzódtak. Az érvelések mögött megtalálhatóak voltak többek között nemzetiségi, gazdasági, egyházi, közigazgatási és geopolitikai megfontolások, vagy éppen az orosz állami szféra intézményei közötti konfliktusokból származó pillanatnyi érdekérvényesítések.

A szerző összegzésében azért tartja különlegesnek (vagy éppen kutatásra méltónak) Besszarábia esetét a jelzett időszakban, mert arra - szemben más orosz határvidékkel - egy frissen létrejött nemzetállam formált igényt. Magam részéről kissé erőltetettnek érzem ezt az önigazolást, főleg annak tükrében, hogy a román külpolitika a cári uralom darabjaira hullásáig marginális ügyként kezelte Besszarábiát a nemzetegyesítés fontossági listáján. Inkább az összegzés későbbi gondolatait tartom relevánsabbnak, amelyek szerint a ma létező identitáskonfliktusok - még akkor is, ha a modern romániai és szovjet konstrukciók által meghatározottak - nem érthetők meg e történelmi előzmények nélkül. Globális viszonylatban pedig továbbra is azt tapasztaljuk, hogy a geopolitikai szereplők az identitások megnyeréséért, alakításáért küzdenek, amelyben a határrégiók - akárcsak 150 évvel ezelőtt - most is a szimbolikus hadviselés kitüntetett színterei.

\section{Köszönetnyilvánítás}

A tanulmány a K 124291 számú, A poszt-szovjet után (?): A változó kelet-európai pufferzóna társadalmi folyamatainak földrajzi vizsgálata című projekt keretében, a Nemzeti Kutatási, Fejlesztési és Innovációs Hivatal (NKFIH) támogatásával készült. 